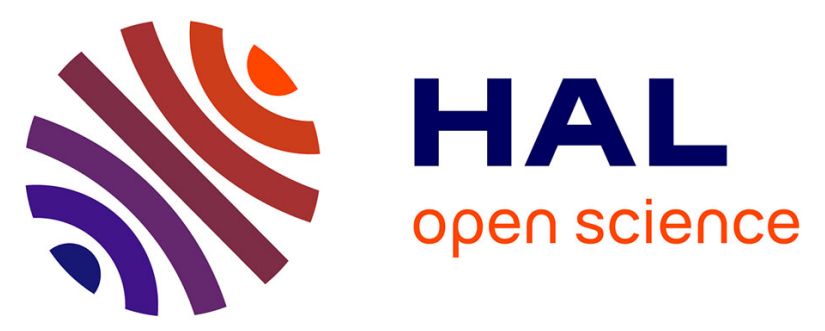

\title{
A quick and low-cost technique to identify layers associated with heavy rainfall in sediment archives during the Anthropocene
}

Anthony Foucher, O. Evrard, Olivier Cerdan, Clément Chabert, François Lecompte, Irène Lefèvre, Rosalie Vandromme, Sebastien Salvador-Blanes

\section{To cite this version:}

Anthony Foucher, O. Evrard, Olivier Cerdan, Clément Chabert, François Lecompte, et al.. A quick and low-cost technique to identify layers associated with heavy rainfall in sediment archives during the Anthropocene. Sedimentology, 2019, 67 (1), pp.sed.12650. 10.1111/sed.12650 . hal-02377280

\section{HAL Id: hal-02377280 \\ https://hal.science/hal-02377280}

Submitted on 26 May 2020

HAL is a multi-disciplinary open access archive for the deposit and dissemination of scientific research documents, whether they are published or not. The documents may come from teaching and research institutions in France or abroad, or from public or private research centers.
L'archive ouverte pluridisciplinaire HAL, est destinée au dépôt et à la diffusion de documents scientifiques de niveau recherche, publiés ou non, émanant des établissements d'enseignement et de recherche français ou étrangers, des laboratoires publics ou privés. 


\section{SEDIMENTOLOGY}

\section{A quick and low-cost technique to identify layers associated with heavy rainfall in sediment archives during the Anthropocene}

\begin{tabular}{|c|c|}
\hline Journal: & Sedimentology \\
\hline Manuscript ID & SED-2019-OM-089 \\
\hline Manuscript Type: & Original Manuscript \\
\hline $\begin{array}{r}\text { Date Submitted by the } \\
\text { Author: }\end{array}$ & 29-Apr-2019 \\
\hline Complete List of Authors: & $\begin{array}{l}\text { Foucher, Anthony; Laboratoire des sciences du climat et de } \\
\text { l'environnement, UMR } 1572 \text { (CEA/CNRS/UVSQ); Université Francois- } \\
\text { Rabelais de Tours, Laboratoire GéoHydrosystemes Continentaux } \\
\text { (GéHCO), E.A 6293, , Faculté des Sciences et Techniques } \\
\text { Evrard, Olivier; Laboratoire des sciences du climat et de } \\
\text { I'environnement, UMR } 1572 \text { (CEA/CNRS/UVSQ) } \\
\text { Cerdan, Olivier; Bureau de Recherches Geologiques et Minieres, } \\
\text { Département Risques et Prévention } \\
\text { Chabert, Clément; Bureau de Recherches Geologiques et Minieres, } \\
\text { Département Risques et Prévention; Laboratoire des sciences du climat } \\
\text { et de I'environnement, UMR } 1572 \text { (CEA/CNRS/UVSQ) } \\
\text { Lecompte, François; Institut National de la Recherche Agronomique, } \\
\text { Plateforme CIRE, Service d'imagerie, UMR PRC } \\
\text { Lefèvre, Irène; Laboratoire des sciences du climat et de l'environnement, } \\
\text { UMR } 1572 \text { (CEA/CNRS/UVSQ) } \\
\text { Vandromme, Rosalie; Bureau de Recherches Geologiques et Minieres, } \\
\text { Département Risques et Prévention } \\
\text { Salvador-Blanes, Sébastien; Université Francois-Rabelais de Tours, } \\
\text { Laboratoire GéoHydrosystèmes Continentaux (GéHCO), E.A 6293, , } \\
\text { Faculté des Sciences et Techniques }\end{array}$ \\
\hline Keywords: & $\begin{array}{l}\text { high resolution density, historical rainfall records, historical floods, } \\
\text { climate change, sediment core, Ct-Scan profiles }\end{array}$ \\
\hline
\end{tabular}


A quick and low-cost technique to identify layers associated with heavy rainfall in sediment archives during the Anthropocene

Anthony Foucher ${ }^{(1,2)}{ }^{*}$, Olivier Evrard ${ }^{(1)}$, Olivier Cerdan ${ }^{(3)}$, Clément Chabert ${ }^{(1,3)}$, François Lecompte ${ }^{(4)}$, Irène Lefèvre ${ }^{(1)}$, Rosalie Vandromme ${ }^{(3)}$, Sébastien Salvador-Blanes (2)

\footnotetext{
(1) Laboratoire des Sciences du Climat et de I'Environnement, (LSCE), UMR 1572 (CEA/CNRS/UVSQ) -Orme des Merisiers, 91191, Gif-surYvette Cedex, France

(2) Laboratoire GéoHydrosystèmes Continentaux (GéHCO), E.A 6293, Université F. Rabelais de Tours, Faculté des Sciences et Techniques, Parc de Grandmont, 37200 Tours, France

(3) Département Risques et Prévention, Bureau de Recherches Géologiques et Minières (BRGM), 3 avenue Claude Guillemin, 45060 Orléans, France

(4) Plateforme CIRE, Service d'imagerie, UMR PRC, Centre INRA Val de Loire, France
}

Corresponding author*: anthony.foucher@outlook.com

\section{Abstract}

Long term records are needed to investigate the impact of extreme events in the current framework of global change. Sedimentary reconstruction with a high resolution remains difficult without conducting expensive, destructive and/or time-consuming analyses. In this study, ultra-high resolution CT-scan profiles $(0.6 \mathrm{~mm}$ resolution) were used for investigating their potential for detecting flood deposits induced by heavy rainfall events. This method was applied to a sediment core - covering a 120 -yr period - collected in a pond draining a small forested catchment (French Massif Central - Central France). Between 1960 and 2017, 28 layers were deposited. Seventy-fixe percent of these deposits were correlated to the occurrence of heavy rainfall $(>50 \mathrm{~mm})$ recorded during 1 or 2 consecutive days. The remainder of the deposits detected with the CT-scan $(n=5)$ were not correlated to weather events. They mainly occurred in response to landscape management operations (e.g. afforestation works posterior to the major 1999 storm). This period was indeed characterized by an increase in the delivery of ${ }^{137} \mathrm{Cs}$-enriched sediment, demonstrating a greater topsoil contribution to sediment during major forest management operations. The intensity of detritical layers has significantly decreased throughout time after a major land use change that took place in 1948 and land abandonment. The frequency of heavy rainfall and associated detritical deposits has nevertheless increased by 60 and 75\% respectively between the 1960-2017 period. These results outline the potential of CT-scan for reconstructing long-term flood deposits associated with heavy precipitation.

Keyword: high resolution density, historical rainfall records, historical floods, climate change, sediment core, CT-Scan 


\section{Introduction}

Identification of heavy precipitation and floods frequency/intensity represents a major challenge for planning adaptation strategies in response to the increase in the frequency of extreme weather conditions expected for the next several decades (Hirabayashi et al., 2013). Classically, historical precipitation records are required to quantify the potential impact of global change on the occurrence of heavy rainfall and flooding events. Despite the significance of precipitation for supplying the water resources required by natural ecosystems, agricultural production or to anticipate disaster risks, the reconstruction of past precipitation has been rarely investigated compared to other climatic parameters such as the temperature (Shabalova et al., 1999; Van Boxel et al., 2014). Improving our knowledge of historical precipitation is particularly timely as a growing number of studies demonstrated the occurrence of significant positive trends in extreme rainfall in Europe (Zolina et al., 2009) and the associated increased flood risk during the $21^{\text {st }}$ century (Christensen \& Christensen, 2003).

Heavy rainfall reconstructions can be obtained at variable temporal scales, from individual years to several decades, based on meteorological measurements (New et al., 2001), historical data (e.g. Macdonald and Black, 2010) or with indirect methods such as river monitoring records (e.g. Evrard et al., 2011; Grangeon et al., 2017). Longer reconstructions (e.g. century/millennium) are more difficult to obtain (e.g. Sakaguchi et al., 2006). In the absence of long-term records of meteorological data or river monitoring, sediment deposition in lakes may provide powerful archives for reconstructing the sequence of significant detrital deposits generated in response to heavy storms (Støren et al., 2016; Wirth et al., 2013). So far, the majority of studies reconstructing precipitation based on sedimentary sequences were conducted on very long time periods (Holocene to millennial scales), and they were generally carried out in mountainous environments (Navratil et al., 2012; Vannière et al., 2013; Wilhelm et al., 2013).

To reach this goal, various proxies were quantified in sedimentary archives to identify and characterize individual detrital deposits (see the review of Schillereff et al., 2014). With most of these methods, it remains difficult to have access to high resolution information without conducting expensive, destructive and/or time-consuming analyses. After the visual description of the sequences (Soutar \& Crill, 1977), these classical measurements include particle size (Arnaud et al., 2002), magnetic susceptibility (Osleger et al., 2009; Støren et al., 2016), 
geochemistry (Hodell et al., 2010), organic matter content (Simonneau et al., 2013; Ishii et al., 2017), colour (Debret et al., 2010) or density (Wheatcroft et al., 2006; St-Onge et al., 2012). These latter density measurements are often used for characterizing sediment cores (St-Onge et al., 2007). Various destructive and non-destructive methods may be used for quantifying this parameter at different spatial resolutions (e.g. dry bulk density, XRF coherence/incoherence ratio, multi-sensor core logger, computer tomography scanner). According to the comparison of methods carried out by Fortin et al. (2013), computer tomography may provide a precise, quick and cost-efficient technique for detecting variations of density in sediment sequences.

The Computer tomography scanner (CT-scan) was increasingly used during recent years in sedimentogical studies (Cnudde \& Boone, 2013). This non-destructive technique may provide high-resolution information on sediment density at a sub-millimeter resolution (Ashi, 1997). In previous studies, this method was successfully used for obtaining high-resolution sediment core imagery (Mena et al., 2015), for determining sediment properties (Tanaka et al., 2011; St-Onge et al., 2012), or for reconstructing sediment cores in 2D/3D (Nakashima and Komatsubara, 2016). CT-Scan presents a clear advantage for detecting and describing high resolution sedimentary facies and structures within sedimentary records (Fortin et al., 2013; Foucher et al., 2014). This technique was already shown to be useful for detecting highresolution cyclicity in sediment cores (e.g paleoclimate oscillation: St-Onge and Long, 2009), instantaneous deposits (Fouinat et al., 2017; Richardson et al., 2018), correlation with changes in particle size (Boespflug et al., 1995), the quantification of biogenic structures (Rosenberg et al., 2007) or again to track flood deposits using a multiproxy approach (Støren et al., 2016).

In the current research, we tested the potential of CT-Scan profiles for detecting at a ultra-high resolution, the frequency of detrital layers deposited in response to heavy rainfall events over the last 120 years. The specific objectives of this article are therefore: (1) to determine the potential of CT-scan to detect the sequence of individual detrital deposits; (2) to correlate these layers with the occurrence of heavy rainfall events during the last 60 years; (3) to estimate the frequency and the intensity of these events during the last century and finally, to identify trends in precipitation.

\section{Site and methods}

\subsection{Site description}


The Prugnolas pond catchment $\left(45^{\circ} 51^{\prime} 52.5^{\prime \prime} \mathrm{N} 1^{\circ} 54^{\prime} 04.0^{\prime \prime} \mathrm{E}\right)$ is a small headwater catchment $\left(7.8 \mathrm{~km}^{2}\right)$ located in the northwestern part of the French Massif Central (highland area), (Fig. 1a \& 1b). This site is situated on the northwestern edge of the Millevaches Natural Regional Park. It corresponds to the first mountainside since the Atlantic Ocean (elevation ranging between 660 and $830 \mathrm{~m}$ a.s.l at the study site) - (Fig. 1b).

Currently, the Prugnolas catchment is - like the Millevaches Natural Park - mostly occupied by forests (respectively $82 \%$ and $70 \%$ of their surface area): the rest of the catchment being covered with artificial or natural grassland (16\% of the Prugnolas catchment area). The surface area occupied by forests significantly increased during the second part of the $20^{\text {th }}$ century: only $30 \%$ of the catchment was occupied by woodland in 1950 (Foucher et al., submitted). Major afforestation works were conducted in the early 1950s (National Office of Forest information).

This region has a humid oceanic climate: average annual precipitations amount to around $1550 \mathrm{~mm}$ (Météo France), and the site is exposed to a large number of Atlantic depressions and storms. During the last century, three major windstorms hit this area in 1951, 1982 and 1999 (with gusting winds reaching up to 169,157 and $130 \mathrm{~km} \cdot \mathrm{h}^{-1}$, respectively (Jubertie, 2006)). In addition, 15 regional historical floods were recorded in this area between 1904 and 2009. Most of them were induced by heavy rainfall events (e.g. 163 and $160 \mathrm{~mm}$ in 1960 and 2001 - Météo France data). Among these regional floods, the 1993, 1982, 1960 and 1944 events have generated extensive damage to infrastructure and housing in those areas located downstream of the investigated catchment. Historical rainfall events and their characteristics were summarized in Table 1.

A small pond dating back to 1645 A.D and located at the catchment outlet has potentially recorded these climatic events (Fig. 1c \& 1d). It is a north-south oriented water body with a surface of $1.8 \mathrm{ha}$. This shallow water body has an average depth of $0.65 \mathrm{~m}$. The deeper part is located in the vicinity of the dam on the north-west $(1.50 \mathrm{~m})$ edge, while the shallowest part is located nearby the progradation of the sandy delta, on the southern part $(0.2 \mathrm{~m}$ depth). The deltaic area extends upstream towards a sandy shallow river.

\subsection{Materials and methods}

Sediment cores $(n=3)$ with a length ranging between 56 and $82 \mathrm{~cm}$ were retrieved in the Prugnolas pond along an upstream-downstream profile (Fig. 1.d) with an Uwitec gravity corer equipped with a $90 \mathrm{~mm}$ PVC liner. 


\section{Laboratory analyses}

Relative sediment density was recorded every $0.6 \mathrm{~mm}$ along the sediment sequences using Computer Tomography (CT-scan) images obtained using those facilities (Siemens Somatom 128 Definition AS scanner) available at the CIRE platform (Surgery and Imaging for Research and Teaching; INRA Val de Loire, France). Relative density values were extracted from the scanner images using the free software ImageJ (Schneider et al., 2012). The relative values of density were calibrated by measuring the absolute dry bulk density $\left(\mathrm{g} . \mathrm{cm}^{-3}\right)$ in samples collected randomly along the cores.

Particle size analyses were undertaken every $0.5 \mathrm{~cm}$ using a Malvern Mastersizer 3000 grain-sizer (allowing theoretically measurements on particle fractions comprised between 0.01 and $3500 \mu \mathrm{m})$. This analysis was performed after removing the organic material with a hydrogen peroxide solution $\left(\mathrm{H}_{2} \mathrm{O}_{2} 30 \%\right.$ during $\left.48 \mathrm{~h}\right)$.

Sediment core dating

The chronology of the master core (23-PR-1701) was established using excess of Lead$210\left({ }^{210} \mathrm{~Pb} \mathrm{ex}_{\mathrm{ex}}\right)$ and Caesium-137 $\left({ }^{137} \mathrm{Cs}\right)$ activities analyzed in 15 samples of dried material $(\sim 10 \mathrm{~g})$. These gamma spectrometry measurements were obtained with the very low background GeHP detectors available at the Laboratoire des Sciences du Climat et de l'Environnement (Gifsur-Yvette, France). Radionuclide activities were decay-corrected to the sampling date (Evrard et al., 2016).

Ages were determined using the Constant Rate of Supply model (CRS), (Appleby \& Oldfield, 1978). This model assumes a constant rate of unsupported Lead-210 $\left({ }^{210} \mathrm{~Pb}_{\mathrm{ex}}\right)$ from atmospheric fallout, although sediment accumulation is allowed to vary. For improving the ${ }^{210} \mathrm{~Pb}_{\mathrm{ex}}$ age model validation, the corrected CRS model described in Appleby (2001) was used. Model validation was carried out through the identification of those deposits tagged with peak ${ }^{137} \mathrm{Cs}$ concentrations. This artificial radionuclide may originate from two sources in Western Europe: thermonuclear weapon testing (maximal emission in 1963) and the Chernobyl accident (1986). To distinguish between both potential ${ }^{137} \mathrm{Cs}$ sources, Americium-241 $\left({ }^{241} \mathrm{Am}\right)$, which regrows from ${ }^{241} \mathrm{Pu}$, was used to identify the ${ }^{137} \mathrm{Cs}$ peak attributed to the maximum nuclear bomb fallout (e.g Cambray et al., 1989).

\section{Rainfall database}

Daily rainfall information was extracted from the SAFRAN climate database produced by the official French meteorological agency (Météo France) and available since 1960 along a $8 \mathrm{~km}$ resolution grid. Four grid points cover the study area, and their mean value was calculated to obtain average weather daily values. 
In addition to these weather data, a database produced by the National Forest Office (ONF), reporting the damages affecting the forest on the study site since 1965 was used. This information is used to check the occurrence of links between major weather events and the disturbance of forested areas. Furthermore, regional data reporting the occurrence of major floods events associated with heavy rainfall - storm events were collected for the last century (French governmental database), Table 1.

\section{Statistical analyses}

The Mann-Kendall non-parametric test (MK-test) was used for detecting monotonic trends in temporal series (Warren \& Gilbert, 1988) and it confirmed the occurrence of monotonic upward or downward trends of a given variable throughout time (with a $p$-value level of 0.05). Trends can be positive, negative or non-null. Then, the non-parametric homogeneity test (Buishand test) was used for detecting the occurrence of changes in temporal series (Buishand, 1982). Buishand test with a $p$-value $<0.05$ indicated a heterogeneous temporal trend between two periods.

\section{Results}

\subsection{Cores description}

The upper part of the three cores was composed of fine (d50:20 $\pm 2 \mu \mathrm{m}$ ) brown-coloured sediment. This layer was rich in pine needles deposited horizontally. The first unit (U1) was found at $15.5 \mathrm{~cm}$ in the $23-\mathrm{PR}-1701$ core and at $50 \mathrm{~cm}$ depth in the 23-PR-1704 core (Fig. 2). The upper $4 \mathrm{~cm}$ of this unit showed a decrease in needle concentrations.

A second unit (U2) was present in the 23-PR-1701 core between 15.5 and $45 \mathrm{~cm}$ depth and between 20 and $42.5 \mathrm{~cm}$ in the 23-PR-1703 core (Fig. 2): U2 was absent from the 23-PR1704 deltaic core. This facies was composed of a fine brown material with properties similar to those found in the first unit ( $\mathrm{d} 50: 18 \pm 2 \mu \mathrm{m})$. The main difference between these two units was the absence of needles and the occurrence of denser sediment in Unit 2 (average density in Unit $1=0.16 \mathrm{~g} . \mathrm{cm}^{-3}$ and Unit $2=0.38 \mathrm{~g} . \mathrm{cm}^{-3}$ ). Within this unit, light-coloured levels identified with the scanner imagery were visible at 28, 29 and $37 \mathrm{~cm}$ in core 23-PR-1703. These layers were also visible at 33 and $36 \mathrm{~cm}$ depths in core 23-PR-1701. These lighter-coloured levels correspond to denser layers.

The transition between U2 and U3 was clearly marked in the 23-PR-1701 and 23-PR1703 cores (respectively at 45 and $42.5 \mathrm{~cm}$ depth), (Fig. 2). U3 was composed of black sediment with a lumpy aspect. This denser layer $\left(0.5 \mathrm{~g} . \mathrm{cm}^{-3}\right)$ was rich in mica and sands. No specific 
sandy layer could be identified in this unit. A coarser deposit was present at the base of the 23PR-1703 core (1 cm diameter gravels at $51 \mathrm{~cm}$ depth).

\subsection{Radionuclide activities and core chronology}

${ }^{137} \mathrm{Cs}$ activities were detected between 20 and $21 \mathrm{~cm}$ depth in the 23-PR-1701 core (4.5 \pm 0.5 Bq. $\mathrm{kg}^{-1}$ ), (Fig. 3). No radio-cesium peak may be clearly attributed to the 1963 fallout in this sequence (Fig. 3). Fallout attributed to 1986 was detected at $11.5 \mathrm{~cm}$ depth $(12.2 \pm 0.8$ Bq. $\mathrm{kg}^{-1}$ ) with a slight increase of ${ }^{137} \mathrm{Cs}$ activity (Fig. 3). In the upper part of the core, concentrations show a significant rise of ${ }^{137} \mathrm{Cs}$ concentrations: activities increased from $9.3 \pm$ $0.6 \mathrm{~Bq} \cdot \mathrm{kg}^{-1}$ at $9 \mathrm{~cm}$ depth to $49.7 \pm 2.2$ at $5 \mathrm{~cm}$ depth (Fig. 3).

The ${ }^{210} \mathrm{~Pb}_{\text {ex }}$ records showed the occurrence of two trends: the first between 1 and $15.5 \mathrm{~cm}$ depth $\left(r^{2}=0.24\right)$ and then the second between 15.5 and $70 \mathrm{~cm}$ depth $\left(r^{2}=0.93\right)$, (Fig. 4). The Log ${ }^{210} \mathrm{~Pb}_{\mathrm{ex}}$ model created for the entire core (linear regression $\mathrm{r}^{2}=0.87$ ) was used to date the transition between the units U1 and U2 to 1982. A major windstorm occurred on that year and left many damages in the forest. The above-mentioned massive deposit of pine needles was attributed to the post-windstorm deposits.

In the upper part of the core, a decline of ${ }^{210} \mathrm{~Pb}_{\mathrm{ex}}$ activities was recorded at 9 and $24 \mathrm{~cm}$ depth. In these levels, concentration decreased from $184 \pm 12$ Bq. $\mathrm{kg}^{-1}\left(17 \mathrm{~cm}\right.$ depth) to $68 \pm 6 \mathrm{~Bq} \cdot \mathrm{kg}^{-}$ ${ }^{1}$ ( $9 \mathrm{~cm}$ depth), and then from $127 \pm 19$ Bq. kg-1 (30 cm depth) to $102 \pm 10 \mathrm{~Bq} \cdot \mathrm{kg}^{-1}$ (24 cm depth). These two layers were dated to 1993 (standard deviation, SD: 0.2 yrs) and 1960 (SD: 0.7 yrs). These periods correspond to the occurrence of two major rainfall events (with respectively 70 and $163 \mathrm{~mm}$ ), which have resulted in historical regional floods. Identification of these layers was in agreement with the age model constructed for the upper part of the core. Additionally, ${ }^{137} \mathrm{Cs}$ time markers were found at the expected level (corresponding to 1986).

For the 1900-1960 period, few stratigraphic layers showed an atypical composition except for the denser deposit detected with the CT-scan at $33 \mathrm{~cm}$ depth and dated to 1942. This layer was attributed to the major regional flood that occurred in 1944.

\subsection{Sediment deposition between 1960-2017}

During the last 57 years (1960-2017), 28 denser layers were identified with the CT-Scan (Fig. 5), with the mean occurrence of a dense layer every 2.1 years (SD: 1.3 year). The detailed properties of these layers are summarized in Table 2. 
The densities extracted from scanner profile were calibrated using density measurements $\left(\mathrm{r}^{2}=0.85\right)$. They ranged between $0.13 \mathrm{~g} . \mathrm{cm}^{-3}$ and $0.57 \mathrm{~g} . \mathrm{cm}^{-3}$ (respectively for layers L8 and L19 (Table 2)), with an average density of $0.2 \mathrm{~g} \cdot \mathrm{cm}^{-3}$ (SD: $0.1 \mathrm{~g} \cdot \mathrm{cm}^{-3}$ ). These values have become significantly lower since 1990. Two levels showed a very high CT-scan intensity in 1982 and in 1960 (L19 and L28), corresponding to the two highest densities found in the upper part of the core (Table 2). These layers remained relatively thin with thicknesses varying between 0.1 and $0.75 \mathrm{~cm}$ (with an average thickness of $0.37 \mathrm{~cm}$ (SD: $0.16 \mathrm{~cm}$ ). Eightytwo $\%$ of the layers showed a thickness lower than $0.5 \mathrm{~cm}$.

In order to compare the link between those denser layers and the occurrence of significant meteorological events, a cumulative rainfall threshold was fixed to identify those 'heavy' rainfall events. For the study area and the wider Massif Central Region, a previous study compiled historical weather information and estimated this limit to $50 \mathrm{~mm}$ within 24 hours (Jubertie, 2006).

For the 1960-2017 period, 23 rainfall events exceeding $50 \mathrm{~mm}$.day ${ }^{-1}$ were recorded in the study site, which represents a frequency of one heavy rainfall event occurring every 2.4 years. The heaviest event was recorded in 1960 with $162-\mathrm{mm}$ cumulative rainfall. The average rainfall amount associated with the heavy events is $63 \mathrm{~mm}$ (SD: $23 \mathrm{~mm}$ ). They occurred mainly during the summer and winter periods, with respectively 33 and $28 \%$ of the events (vs. 19 and 18\% during spring and autumn). A lower proportion of these events (25\%) occurred during the same year (with only few months between successive events). Consequently, individual events occurring within the same year were likely not distinguished. A total of 16 individual heavy rainfall events were finally selected.

In addition of these individual daily events, those events generating cumulative rainfall exceeding $50 \mathrm{~mm}$ during two successive days were also identified. During the 1960-2017 period, seven 2-day events were found, with rainfall ranging from 82 to $160 \mathrm{~mm}$ (mean: 97 $\mathrm{mm}, \mathrm{SD}: 28 \mathrm{~mm})$.

Among the 28 denser sediment layers detected with the scan, 14 units were correlated to intense daily rainfall (52\%) and 7 of these were associated with two-day cumulative rainfall (26\%). The other layers could not be correlated to heavy rainfall events (Table 2). Errors associated with the corresponding years were estimated between -0.9 and +1.3 year (mean: 0.1 yr, SD: 0.48 year). Among the selected rainfall events, only two rainstorms (those of 1969 and 2010) could not be associated with sediment layers in the Prugnolas sedimentary archive.

Changes in particle size measured with a $0.5 \mathrm{~cm}$ resolution were observed in $26 \%$ of the 28 levels detected with the scanner imagery $(n=7)$ in the upper part of the core. 
The d50s of these layers ranged between 19.4 and $25.7 \mu \mathrm{m}$ with an average value of $23.4 \mu \mathrm{m}$ (SD: $2.3 \mu \mathrm{m}$ ). The d50 in all the layers of the upper part of the core was around $17.2 \mu \mathrm{m}$ (SD: $0.5 \mu \mathrm{m})$. Of the seven layers with a coarser particle size, six were associated with the occurrence of a heavy rainfall event.

\subsection{Sediment deposition between $1900-1960$}

Data extracted from the CT-Scan records showed the occurrence of 30 denser layers during this 60 year period, which represents on average one event every 1.7 year (SD: 0.7 year). (Fig. 6). The densities of these levels ranged between 0.24 g.cm ${ }^{-3}$ and 0.9 g.cm ${ }^{-3}$ (respectively

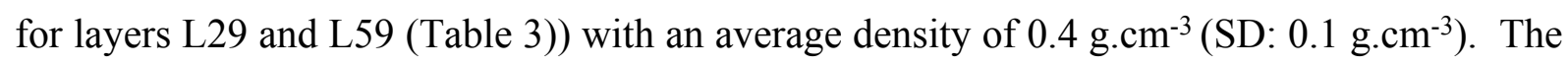
CT-scan intensity of these deposits was clearly higher than in those layers identified in the upper part of the core especially for the layers L34, 37, 44, 46, 57 and 59 (deposited respectively in 1944, 1938, 1927, 1922, 1905 and 1903 according to the ${ }^{210} \mathrm{~Pb}_{\mathrm{ex}}$ model). (Table 3).

These layers were relatively thin with values ranging between 0.1 and $1.1 \mathrm{~cm}$ respectively for layers L47 and L40, with an average thickness of $0.5 \mathrm{~cm}$ (SD: $0.22 \mathrm{~cm}$ ). Sixtythree $\%$ of the detected layers had a thickness lower than $0.5 \mathrm{~cm}$.

In contrast to the period covered in the upper part of the core, no daily meteorological data was available for the 1900-1960 period to test the occurrence of a correlation between those denser deposits and heavy rainfall events or major human disturbances.

\section{Discussion}

CT-scan imagery provided an effective technique for the detection with a ultra-high resolution of 58 denser layers that deposited in this lake during the last century. These deposits were highly correlated to the occurrence of heavy daily or two-day rainfall events $(75 \% ; n=21$ rainfall events $>50 \mathrm{~mm}$ ) during the period for which rainfall monitoring was available (last 60 years, $n=28$ deposits). Only one layer, L19 (1982), was associated with a less intense event (41 mm.day ${ }^{-1}$ ) and a windstorm. This event triggered a regional flood. These results demonstrate the high potential of this proxy for detecting individual detritical layers generated by intense rainfall events during a period of lower anthropogenic impact. This high resolution proxy (0.6 $\mathrm{mm}$ ) is not the only indicator used to reach this goal. Previous research has already successfully made a correlation between meteorological data (rainfall, flood or windstorm events) and other 
high resolution sedimentary proxies (e.g Affouri et al., 2017). For example, winter rainfall was reconstructed over the last 500 years using thickness of annual calcite deposited in sedimentary deposits with a $15 \mu \mathrm{m}$ resolution in Spain (Romero-Viana et al., 2011). In the foothills of the Spanish Pyrenees, detritical layers were detected in a varved lake for reconstructing those trends in heavy rainfall (Corella et al., 2016). In Germany, windstorms were identified during the 1961-2001 period using quartz grain size (micrometer resolution; Pfahl et al., 2009). Other studies mainly focused on the identification of major historical events using a large variety of proxies (e.g. grain size, radionuclides, geochemistry), (e.g. Chapron et al., 2007; Dhivert et al., 2015) although they generally achieved a lower temporal resolution.

In the current research, CT-scan data allowed the detection of the majority of those intense rainfall events. Furthermore, every known historical event recorded in the lower part of the Prugnolas catchment during the last 60 years was identified in this sequence $(1995,1993,1990$, $1986,1982,1979,1963$ and 1960). Four of these events were associated with a decline in ${ }^{210} \mathrm{~Pb}_{\mathrm{ex}}$ concentrations (1995, 1993, 1986 and 1960). In uncultivated soil, the maximum ${ }^{210} \mathrm{~Pb}_{\mathrm{ex}}$ concentration is found near the surface (in the top $10 \mathrm{~cm}$, Caitcheon et al., 2012). Accordingly, a low concentration of this radionuclide indicates a dominant contribution of sediment originating from deeper soil erosion, channel or gully erosion (Evrard et al., 2016). These four regional floods were amongst the most destructive experienced over the last 60 years. The observed decrease of ${ }^{210} \mathrm{~Pb}_{\mathrm{ex}}$ concentrations for the corresponding periods may reflect an increase of gully and channel erosion. Accordingly, the combined use of CT-Scan and radionuclide analyses may provide a powerful technique to identify the source of flood deposits.

However, several detritical layers were not correlated to intense rainfall events $(18 \%$, $\mathrm{n}=5$ ). They were likely associated with human management operations (afforestation works) within the catchment, especially after $2000(n=3)$. The 1999 storm is the most powerful hurricane recorded over the last century in this region (maximum wind speed of $148 \mathrm{~km} / \mathrm{h}$, in Limoges (Fig. 1)). It devastated a significant portion of the forest cover. Nearby the pond, 15 ha of forest fell down. However, neither an increase of the corresponding layer density nor the occurrence of an intense rainfall event was associated with this windstorm. From 2001-2002 onwards, forest management operations were implemented in the catchment to clear the fallen trees and replant these surfaces. These practices were recorded in the sediment sequence accumulated in the pond as a change in sediment properties reflecting a change of sediment source was observed. Accordingly, ${ }^{137} \mathrm{Cs}$ activities increased 5-fold from $10.3 \pm 0.7 \mathrm{~Bq} \cdot \mathrm{kg}^{-1} \mathrm{in}$ 1995 to $55.1 \pm 2.5 \mathrm{~Bq} \cdot \mathrm{kg}^{-1}$ in $2005 .{ }^{137} \mathrm{Cs}$ is predominantly fixed to fine particles (He \& Walling, 1996; Wallbrink \& Murray, 1996). In undisturbed soils, this radionuclide remains concentrated 
near the surface with a concentration decreasing exponentially with depth (e.g. Matisoff et al., 2005). In contrast, in cultivated soils, the ${ }^{137} \mathrm{Cs}$ is homogenized by tillage (Olley et al., 2013). Sediment supplied by the erosion of surface layers often have elevated ${ }^{137} \mathrm{Cs}$ concentrations whereas sediment generated by subsoil erosional processes, like channel bank erosion, show low ${ }^{137} \mathrm{Cs}$ concentrations (Foucher et al., 2015; Lepage et al., 2015; Le Gall et al., 2017). The supply of sediment with elevated ${ }^{137} \mathrm{Cs}$ concentrations after the 1999 windstorm therefore likely reflects a shift in sediment sources with an increase of surface soil contributions associated with the major management disturbances observed in forest areas. This period of increased sediment connectivity likely facilitated the transfer of material from upper parts of the catchment to the pond during less intense rainfall events than during the previous periods (Paimin, 2017). Those detritical layers, which were not correlated to major rainfall events $(2015,2009,2005)$, were therefore likely generated by events with lower rainfall intensities during a period of human disturbance nearby the pond.

Over the entire centennial sequences, a significant decline in deposit intensity was observed (Mann-Kendall test - $p$-value $<0,0001)-\left(\mathrm{r}^{2}=0.55\right)$, (Fig. 7). Homogeneity Buishand statistical test ( $p$-value $<0,0001)$ showed the occurrence of a break-in-slope in this negative trend around 1970-1971.

During the $20^{\text {th }}$ century, land cover in this region changed significantly, with the massive conversion of cropland and grassland into forests in response to the rural depopulation (after the end of WWII) - (Foucher et al., submitted). Deforestation and cultivation rank with urbanization among the major factors increasing flood severity and frequency at the catchment scale (de la Paix et al., 2011; Reinhardt-Imjela et al., 2018). Previous research also showed that land use change has even more pronounced effects on flood severity in smaller catchments (Tollan, 2002). Progressive land abandonment and afforestation in the Prugnolas catchment likely generated a decrease of the sediment quantity supplied to the lake during intense rainfall events with the extensive development of forest cover. Although this remains debated in the literature, the planting of forests to act as a buffer against floods appears to be effective in small catchments (van Dijk et al., 2009; Bradford et al., 2012).

In the Prugnolas Pond sediment sequence, the occurrence of detritical layers associated with intense rainfall events ( $>50 \mathrm{~mm}$ per day/two days for this site) has shifted from the occurrence of 5 events between 1960 and 1970 to that of 8 events between 2000 and $2010(60 \%$ increase). In the meantime, the number of denser sediment layers increased for 4 units between 1960 and 1970 to 7 units between 2000-2010 (75\% increase), (Fig. 8). Both trends are correlated $\left(r^{2}=0.60\right)$. However, no statistically significant trend was clearly detected during the last 57 
years using the Mann-Kendal test ( $p$-value of 0.132). In the same way, no similar trend was detected at the scale of the last century ( $p$-value of 0.56 ). These results are in agreement with those of modelling studies which showed the stable occurrence of heavy precipitation in this part of Europe (Frei et al., 2006).

Conclusions

This study demonstrated the potential of analyzing CT-scan proxies in sediment cores for detecting individual flood deposits associated with the occurrence of heavy rainfall. This robust and cost-efficient method produced ultra-high resolution data of the core relative density. Extracted values were used for identifying changes in density within a centennial sedimentary archive. After their dating with radionuclides, these layers were compared to the daily meteorological data available in the study area since 1960. A strong correlation was found between the occurrence of heavy precipitation and those denser layers during the period devoid of major human management (prior to 2000). Moreover, all historical regional floods were associated with CT-scan peaks. When combined with the ${ }^{210} \mathrm{~Pb}$ ex radionuclide records, this method proved to provide a powerful technique to identify the impact of the major regional destructive floods (1995, 1993, 1982 and 1960), which supplied sediment originating from channel bank erosion.

Accordingly, CT-Scan-derived proxy may provide an additional tool for the community of sedimentologists in order to identify with a ultra-high resolution those changes in sediment records induced by anthropogenic or climatic disturbances. This method may provide a rapid high resolution characterization of the sedimentary archive before the coupling of this information with other proxies. Future research should examine the potential of this tool for reconstructing heavy rainfall series over longer time scales. Providing an improved technique to achieve this goal could contribute to improve our understanding of the impact of global changes in rainfall intensity and frequency and our capacities for predicting long term trends affecting the occurrence of extreme rainfall events.

\section{Acknowledgements}

The authors are grateful to Anne Colmar, Xavier Bourrain and Jean-Noël Gautier for their technical and financial support. This work was supported by a grant from the Loire- 
Brittany Water Agency (METEOR project). The authors would also like to thank Jerome Vany (Office National des Forêts) and Peggy Chevilley (Communauté de Commune de Bourganeuf) for their precious historical information on the studied catchment. Authors gratefully acknowledge Naresh Kumar and Anastasiia Bagaeva for their help during the field survey.

\section{References}

Affouri, A., Dezileau, L. and Kallel, N. (2017) Extreme flood event reconstruction spanning the last century in the El Bibane Lagoon (southeastern Tunisia): a multi-proxy approach. Clim. Past, 13, 711-727.

Appleby, P.G. (2001) Tracking Environmental Change Using Lake Sediments. Volume 1: Basin Analysis, Coring, and Chronological Techniques. 171-201 pp.

Appleby, P.G. and Oldfield, F. (1978) The calculation of lead-210 dates assuming a constant rate of supply of unsupported $210 \mathrm{~Pb}$ to the sediment. Catena, $\mathbf{5}, 1-8$.

Arnaud, F., Lignier, V., Revel, M., Desmet, M., Beck, C., Pourchet, M., Charlet, F., Trentesaux, A. and Tribovillard, N. (2002) Flood and earthquake disturbance of $210 \mathrm{~Pb}$ geochronology (Lake Anterne, NW Alps). Terra Nov., 14, 225-232.

Ashi, J. (1997) Computed Tomography Scan Image Analysis of Sediments. Proc. Ocean. Drill. Program, Sci. Results, 156, 151-159.

Boespflug, X., Long, B.F.N. and Occhietti, S. (1995) CAT-scan in marine stratigraphy: a quantitative approach. Mar Geol. doi: 10.1016/0025-3227(94)00129-9

\section{Bradford, R.A., O’Sullivan, J.J., Van Der Craats, I.M., Krywkow, J., Rotko, P.,} Aaltonen, J., Bonaiuto, M., De Dominicis, S., Waylen, K. and Schelfaut, K. (2012) Risk perception - Issues for flood management in Europe. Nat. Hazards Earth Syst. Sci., 12, 2299-2309.

Buishand, T.A. (1982) Some methods for testing the homogeneity of rainfall records. J Hydrol. doi: 10.1016/0022-1694(82)90066-X

Caitcheon, G.G., Olley, J.M., Pantus, F., Hancock, G. and Leslie, C. (2012) The dominant erosion processes supplying fine sediment to three major rivers in tropical Australia, the 
Daly (NT), Mitchell (Qld) and Flinders (Qld) Rivers. Geomorphology. doi:

10.1016/j.geomorph.2012.02.001

Cambray, R.S., Playford, K. and Carpenter, R.C. (1989) Radioactive Fallout in Air and Rain: Results to the End of 1988.

Chapron, E., Juvigné, E., Mulsow, S., Ariztegui, D., Magand, O., Bertrand, S., Pino, M. and Chapron, O. (2007) Recent clastic sedimentation processes in Lake Puyehue (Chilean Lake District, $40.5^{\circ} \mathrm{S}$ ). Sediment. Geol., 201, 365-385.

Christensen, J.H. and Christensen, O.B. (2003) Severe summertime flooding in Europe. Nature, 421, 805.

Cnudde, V. and Boone, M.N. (2013) High-resolution X-ray computed tomography in geosciences: A review of the current technology and applications. Earth-Science Rev. 123:1-17.

Corella, J.P., Valero-Garcés, B.L., Vicente-Serrano, S.M., Brauer, A. and Benito, G. (2016) Three millennia of heavy rainfalls in Western Mediterranean: Frequency, seasonality and atmospheric drivers. Sci Rep. doi: 10.1038/srep38206

de la Paix, M.J., Lanhai, L., Xi, C., Ahmed, S. and Varenyam, A. (2011) SOIL DEGRADATION AND ALTERED FLOOD RISK AS A CONSEQUENCE OF DEFORESTATION. L. Degrad. Dev., n/a-n/a.

Debret, M., Chapron, E., Desmet, M., Rolland-Revel, M., Magand, O., Trentesaux, A., Bout-Roumazeille, V., Nomade, J. and Arnaud, F. (2010) North western Alps Holocene paleohydrology recorded by flooding activity in Lake Le Bourget, France. Quat. Sci. Rev., 29, 2185-2200.

Dhivert, E., Grosbois, C., Coynel, A., Lefèvre, I. and Desmet, M. (2015) Influences of major flood sediment inputs on sedimentary and geochemical signals archived in a reservoir core (Upper Loire Basin, France). CATENA, 126, 75-85.

Evrard, O., Laceby, J.P., Onda, Y., Wakiyama, Y., Jaegler, H. and Lefèvre, I. (2016) Quantifying the dilution of the radiocesium contamination in Fukushima coastal river sediment (2011-2015). Sci. Rep., 6, 34828.

Evrard, O., Navratil, O., Ayrault, S., Ahmadi, M., Némery, J., Legout, C., Lefèvre, I., Poirel, A., Bonté, P. and Esteves, M. (2011) Combining suspended sediment 
monitoring and fingerprinting to determine the spatial origin of fine sediment in a mountainous river catchment. Earth Surf Process Landforms. doi: 10.1002/esp.2133

Fortin, D., Francus, P., Gebhardt, A.C., Hahn, A., Kliem, P., Lisé-Pronovost, A., Roychowdhury, R., Labrie, J. and St-Onge, G. (2013) Destructive and non-destructive density determination: Method comparison and evaluation from the Laguna Potrok Aike sedimentary record. Quat. Sci. Rev., 71, 147-153.

Foucher, A., Evrard, O., Chabert, C., Cerdan, O., Lefèvre, I., Vandromme, R. and Salvador-Blanes, S. Erosional response to land abandonment in rural areas of Western Europe during the Anthropocene: a case study in the Massif-Central, France.

Foucher, A., Patrick Laceby, J., Salvador-Blanes, S., Evrard, O., Le Gall, M., Lefèvre, I., Cerdan, O., Rajkumar, V. and Desmet, M. (2015) Quantifying the dominant sources of sediment in a drained lowland agricultural catchment: The application of a thorium-based particle size correction in sediment fingerprinting. Geomorphology. doi: 10.1016/j.geomorph.2015.09.007

Foucher, A., Salvador-Blanes, S., Evrard, O., Simonneau, A., Chapron, E., Courp, T., Cerdan, O., Lefèvre, I., Adriaensen, H., Lecompte, F. and Desmet, M. (2014) Increase in soil erosion after agricultural intensification: Evidence from a lowland basin in France. Anthropocene, 7, 30-41.

Fouinat, L., Sabatier, P., Poulenard, J., Reyss, J.L., Montet, X. and Arnaud, F. (2017) A new CT scan methodology to characterize a small aggregation gravel clast contained in a soft sediment matrix. Earth Surf. Dyn., 5, 199-209.

Frei, C., Schöll, R., Fukutome, S., Schmidli, J. and Vidale, P.L. (2006) Future change of precipitation extremes in Europe: Intercomparison of scenarios from regional climate models. J Geophys Res Atmos. doi: 10.1029/2005JD005965

Grangeon, T., Manière, L., Foucher, A., Vandromme, R., Cerdan, O., Evrard, O., PeneGalland, I. and Salvador-Blanes, S. (2017) Hydro-sedimentary dynamics of a drained agricultural headwater catchment: A nested monitoring approach. Vadose Zo J. doi: $10.2136 /$ vzj2017.05.0113

He, Q. and Walling, D.E. (1996) Interpreting particle size effects in the adsorption of 137Cs and unsupported $210 \mathrm{~Pb}$ by mineral soils and sediments. J Environ Radioact. doi: $10.1016 / 0265-931 X(96) 89275-7$ 
Hirabayashi, Y., Mahendran, R., Koirala, S., Konoshima, L., Yamazaki, D., Watanabe, S., Kim, H. and Kanae, S. (2013) Global flood risk under climate change. Nat. Clim. Chang., 3, 816-821.

Hodell, D.A., Evans, H.F., Channell, J.E.T. and Curtis, J.H. (2010) Phase relationships of North Atlantic ice-rafted debris and surface-deep climate proxies during the last glacial period. Quat. Sci. Rev., 29, 3875-3886.

Ishii, Y., Hori, K. and Momohara, A. (2017) Middle to late Holocene flood activity estimated from loss on ignition of peat in the Ishikari lowland, northern Japan. Glob. Planet. Change, 153, 1-15.

Jubertie, F. (2006) Les excès climatiques dans le Massif central français. L'impact des temps forts pluviométriques et anémométriques en Auvergne. Université Blaise Pascal Clermont-Ferrand II

Le Gall, M., Evrard, O., Thil, F., Foucher, A., Laceby, J.P., Manière, L., SalvadorBlanes, S. and Ayrault, S. (2017) Examining suspended sediment sources and dynamics during flood events in a drained catchment using radiogenic strontium isotope ratios (87Sr/86Sr). Chem. Geol., 449, 147-157.

Lepage, H., Evrard, O., Onda, Y., Chartin, C., Lefevre, I., Sophie, A. and Bonte, P. (2015) Tracking the origin and dispersion of contaminated sediments transported by rivers draining the Fukushima radioactive contaminant plume. Proc. Int. Assoc. Hydrol. Sci., 367, 237-243.

Macdonald, N. and Black, A.R. (2010) Reassessment of flood frequency using historical information for the River Ouse at York, UK (1200-2000). Hydrol. Sci. J., 55, 11521162.

Matisoff, G., Wilson, C.G. and Whiting, P.J. (2005) The7Be/210Pbxs ratio as an indicator of suspended sediment age or fraction new sediment in suspension. Earth Surf. Process. Landforms, 30, 1191-1201.

Mena, A., Francés, G., Pérez-Arlucea, M., Aguiar, P., Barreiro-Vázquez, J.D., Iglesias, A. and Barreiro-Lois, A. (2015) A novel sedimentological method based on CTscanning: Use for tomographic characterization of the Galicia Interior Basin. Sediment. Geol., 321, 123-138. 
Nakashima, Y. and Komatsubara, J. (2016) Seismically induced soft-sediment deformation structures revealed by X-ray computed tomography of boring cores. Tectonophysics, 683, $138-147$.

Navratil, O., Evrard, O., Esteves, M., Legout, C., Ayrault, S., Némery, J., Mate-Marin, A., Ahmadi, M., Lefèvre, I., Poirel, A. and Bonté, P. (2012) Temporal variability of suspended sediment sources in an alpine catchment combining river/rainfall monitoring and sediment fingerprinting. Earth Surf Process Landforms. doi: 10.1002/esp.3201

New, M., Todd, M., Hulme, M. and Jones, P. (2001) Precipitation measurements and trends in the twentieth century. Int. J. Climatol., 21, 1889-1922.

Olley, J., Burton, J., Smolders, K., Pantus, F. and Pietsch, T. (2013) The application of fallout radionuclides to determine the dominant erosion process in water supply catchments of subtropical South-east Queensland, Australia. Hydrol Process. doi: 10.1002/hyp.9422

Osleger, D.A., Heyvaert, A.C., Stoner, J.S. and Verosub, K.L. (2009) Lacustrine turbidites as indicators of Holocene storminess and climate: Lake Tahoe, California and Nevada. $J$. Paleolimnol., 42, 103-122.

Paimin, P. (2017) The Effectiveness of Mahogany (Swietenia macrophylla) Plantation Forest on Controlling Erosion and Runoff. Forum Geogr., 19, 88.

Pfahl, S., Sirocko, F., Seelos, K., Dietrich, S., Walter, A. and Wernli, H. (2009) A new windstorm proxy from lake sediments: A comparison of geological and meteorological data from western Germany for the period 1965-2001. J. Geophys. Res., 114, D18106.

Reinhardt-Imjela, C., Imjela, R., Bölscher, J. and Schulte, A. (2018) The impact of late medieval deforestation and 20th century forest decline on extreme flood magnitudes in the Ore Mountains (Southeastern Germany). Quat Int. doi: 10.1016/j.quaint.2017.12.010

Richardson, K.N.D., Hatten, J.A. and Wheatcroft, R.A. (2018) 1500 years of lake sedimentation due to fire, earthquakes, floods and land clearance in the Oregon Coast Range: geomorphic sensitivity to floods during timber harvest period. Earth Surf. Process. Landforms, 43, 1496-1517.

Romero-Viana, L., Julià, R., Schimmel, M., Camacho, A., Vicente, E. and Miracle, M.R. (2011) Reconstruction of annual winter rainfall since A.D.1579 in central-eastern Spain 
based on calcite laminated sediment from Lake La Cruz. Clim Change. doi: 10.1007/s10584-010-9966-7

Rosenberg, R., Davey, E., Gunnarsson, J., Norling, K. and Frank, M. (2007) Application of computer-aided tomography to visualize and quantify biogenic structures in marine sediments. Mar Ecol Prog Ser. doi: 10.3354/meps331023

Sakaguchi, A., Yamamoto, M., Sasaki, K. and Kashiwaya, K. (2006) Uranium and thorium isotope distribution in an offshore bottom sediment core of the Selenga Delta, Lake Baikal, Siberia. J. Paleolimnol., 35, 807-818.

Schillereff, D.N., Chiverrell, R.C., Macdonald, N. and Hooke, J.M. (2014) Flood stratigraphies in lake sediments: A review. Earth-Science Rev. 135:17-37.

Schneider, C.A., Rasband, W.S. and Eliceiri, K.W. (2012) NIH Image to ImageJ: 25 years of image analysis. Nat. Methods, 9, 671-675.

Shabalova, M. V., Können, G.P. and Borzenkova, I.I. (1999) Precipitation change: Model simulations and paleoreconstructions. Clim Change. doi: 10.1023/A:1005455707323

Simonneau, A., Chapron, E., Courp, T., Tachikawa, K., Le Roux, G., Baron, S., Galop, D., Garcia, M., Di Giovanni, C., Motellica-Heino, M., Mazier, F., Foucher, A., Houet, T., Desmet, M. and Bard, E. (2013) Recent climatic and anthropogenic imprints on lacustrine systems in the Pyrenean Mountains inferred from minerogenic and organic clastic supply (Vicdessos valley, Pyrenees, France). Holocene. doi: $10.1177 / 0959683613505340$

Soutar, A. and Crill, P.A. (1977) Sedimentation and climatic patterns in the Santa Barbara Basin during the 19th and 20th centuries. Bull. Geol. Soc. Am., 88, 1161-1172.

St-Onge, G., Chapron, E., Mulsow, S., Salas, M., Viel, M., Debret, M., Foucher, A., Mulder, T., Winiarski, T., Desmet, M., Costa, P.J.M., Ghaleb, B., Jaouen, A. and Locat, J. (2012) Comparison of earthquake-triggered turbidites from the Saguenay (Eastern Canada) and Reloncavi (Chilean margin) Fjords: Implications for paleoseismicity and sedimentology. Sediment. Geol., 243-244, 89-107.

St-Onge, G. and Long, B.F. (2009) CAT-scan analysis of sedimentary sequences: An ultrahigh-resolution paleoclimatic tool. Eng. Geol., 103, 127-133.

St-Onge, G., Mulder, T., Francus, P. and Long, B. (2007) Chapter Two Continuous 
Physical Properties of Cored Marine Sediments. Dev. Mar. Geol. 1:63-98.

Støren, E.W.N., Paasche, Ø., Hirt, A.M. and Kumari, M. (2016) Magnetic and geochemical signatures of flood layers in a lake system. Geochemistry, Geophys. Geosystems, 17, 4236-4253.

Tanaka, A., Nakano, T. and Ikehara, K. (2011) X-ray computerized tomography analysis and density estimation using a sediment core from the Challenger Mound area in the Porcupine Seabight, off Western Ireland. Earth, Planets Sp., 63, 103-110.

Tollan, A. (2002) Land-use change and floods: what do we need most, research or management?

Van Boxel, J.H., González-Carranza, Z., Hooghiemstra, H., Bierkens, M. and Vélez, M.I. (2014) Reconstructing past precipitation from lake levels and inverse modelling for Andean Lake La Cocha. J Paleolimnol. doi: 10.1007/s10933-013-9755-1

Van den Besselaar, E.J.M., Klein Tank, A.M.G. and Buishand, T.A. (2013) Trends in European precipitation extremes over 1951-2010. Int. J. Climatol., 33, 2682-2689.

van Dijk, A.I.J.M., van Noordwijk, M., Calder, I.R., Bruijnzeel, S.L.A., Schellekens, J.A.A.P. and Chappell, N.A. (2009) Forest-flood relation still tenuous - Comment on 'Global evidence that deforestation amplifies flood risk and severity in the developing world'by C. J. A. Bradshaw, N.S. Sodi, K. S.-H. Peh and B.W. Brook. Glob. Chang. Biol.

Vannière, B., Magny, M., Joannin, S., Simonneau, A., Wirth, S.B., Hamann, Y., Chapron, E., Gilli, A., Desmet, M. and Anselmetti, F.S. (2013) Orbital changes, variation in solar activity and increased anthropogenic activities: Controls on the Holocene flood frequency in the Lake Ledro area, Northern Italy. Clim. Past, 9, 11931209.

Wallbrink, P.J. and Murray, A.S. (1996) Distribution and variability of 7Be in soils under different surface cover conditions and its potential for describing soil redistribution processes. Water Resour Res. doi: 10.1029/95WR02973

Warren, J. and Gilbert, R.O. (1988) Statistical Methods for Environmental Pollution Monitoring. Technometrics. doi: 10.2307/1270090

Wheatcroft, R.A., Stevens, A.W., Hunt, L.M. and Milligan, T.G. (2006) The large-scale 
distribution and internal geometry of the fall 2000 Po River flood deposit: Evidence from digital X-radiography. Cont. Shelf Res., 26, 499-516.

Wilhelm, B., Arnaud, F., Sabatier, P., Magand, O., Chapron, E., Courp, T., Tachikawa, K., Fanget, B., Malet, E., Pignol, C., Bard, E. and Delannoy, J.J. (2013) Palaeoflood activity and climate change over the last 1400 years recorded by lake sediments in the north-west European Alps. J. Quat. Sci., 28, 189-199.

Wirth, S.B., Gilli, A., Simonneau, A., Ariztegui, D., Vannière, B., Glur, L., Chapron, E., Magny, M. and Anselmetti, F.S. (2013) A 2000 year long seasonal record of floods in the southern European Alps. Geophys. Res. Lett., 40, 4025-4029.

Zolina, O., Simmer, C., Belyaev, K., Kapala, A. and Gulev, S. (2009) Improving Estimates of Heavy and Extreme Precipitation Using Daily Records from European Rain Gauges. J. Hydrometeorol., 10, 701-716.

Figure captions

Figure 1: Study site location in France: (a) General localization of the study site and track of the 1999 storm, (b) topographic map and profile for the western part of the Massif Central localization of the Millevache National Park, (c) Prugnolas catchment map, (d) Prugnolas pond map: localization of the collected cores

Figure 2: Definition of the sedimentary units along the master core 23-PR-1701 using CTScan imagery/grey values, K/Ca ratio and grain size analyses (d90). Correlation with the 23PR-1702 and 23-PR-1704 cores.

Figure 3: Evolution of ${ }^{137} \mathrm{Cs}$ activities with depth in core 23-PR-1701

Figure 4: Age depth model of core 23-PR-1701 based on ${ }^{210} \mathrm{~Pb}_{\mathrm{ex}}$ corrected Constant Rate Supply model. Model validation was achieved by the identification of those ${ }^{137} \mathrm{Cs}$ fallout peaks and the visual identification of sediment layers associated with flood events. 
Figure 5: Detection with CT-scan profile of denser layers for the 2017-1960 period. Comparison with daily and two-days extreme rainfall $(>50 \mathrm{~mm})$.

Figure 6: Detection with CT-scan profile of denser layers for the 1960-1900 period.

Figure 7: Evolution of flood sediment deposit intensity $\left(\mathrm{g} . \mathrm{cm}^{-3}\right)$ during the last 120 years in the Prugnolas pond using the 23-PR-1701 core

Figure 8: Trend in frequency of heavy rainfall and denser layer records during the monitored period (2017-1960) years in the Prugnolas pond using the 23-PR-1701 core

Table caption

Table 1: Historical climatic events record in the vicinity of the Prugnolas catchment

Table 2: Properties of detritical layers deposited between 2017 and 1960

Table 3: Properties of detritical layers deposited between 1960 and 1900 


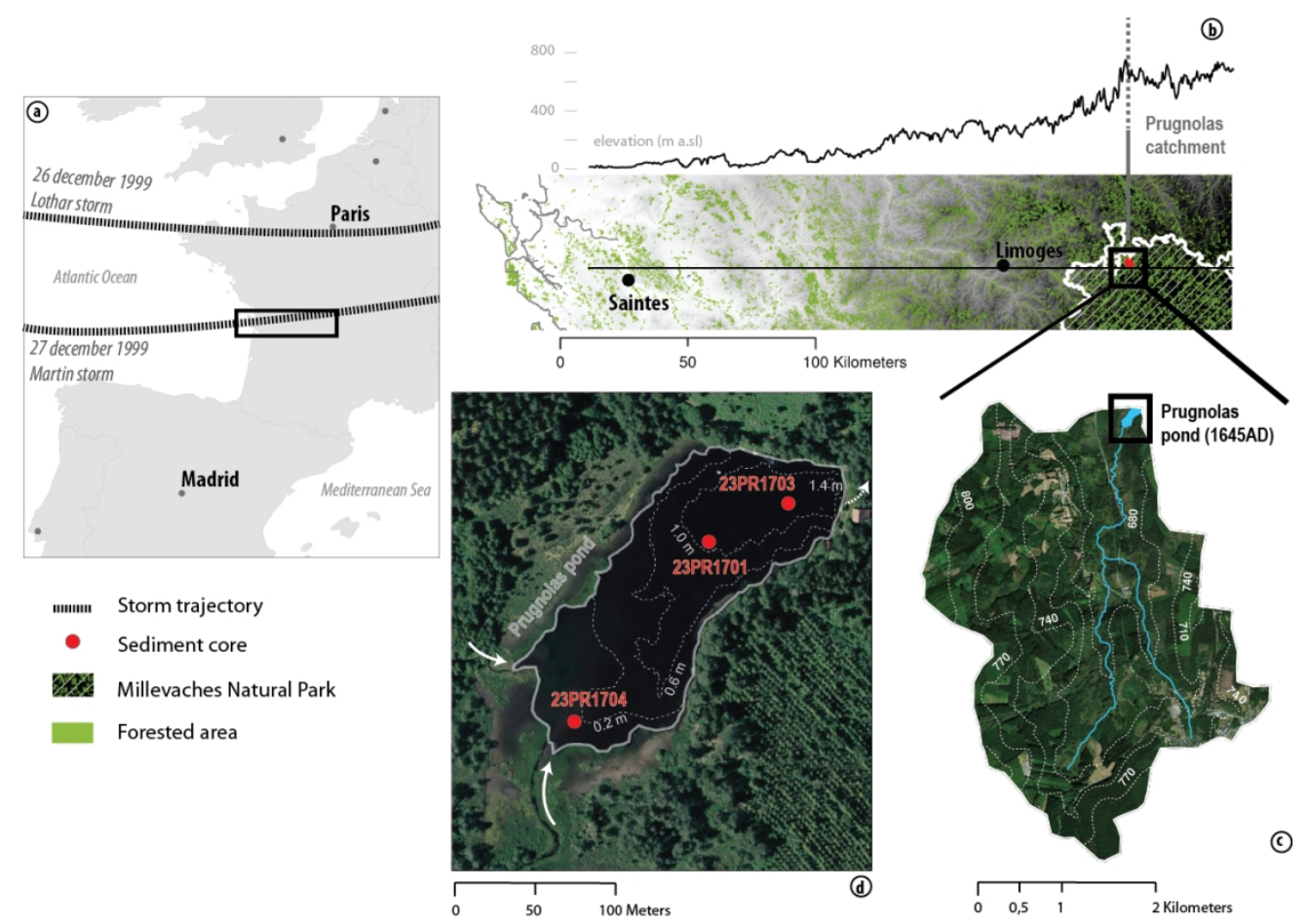

Figure 1: Study site location in France: (a) General localization of the study site and track of the 1999 storm, (b) topographic map and profile for the western part of the Massif Central - localization of the Millevache National Park, (c) Prugnolas catchment map, (d) Prugnolas pond map: localization of the collected cores 


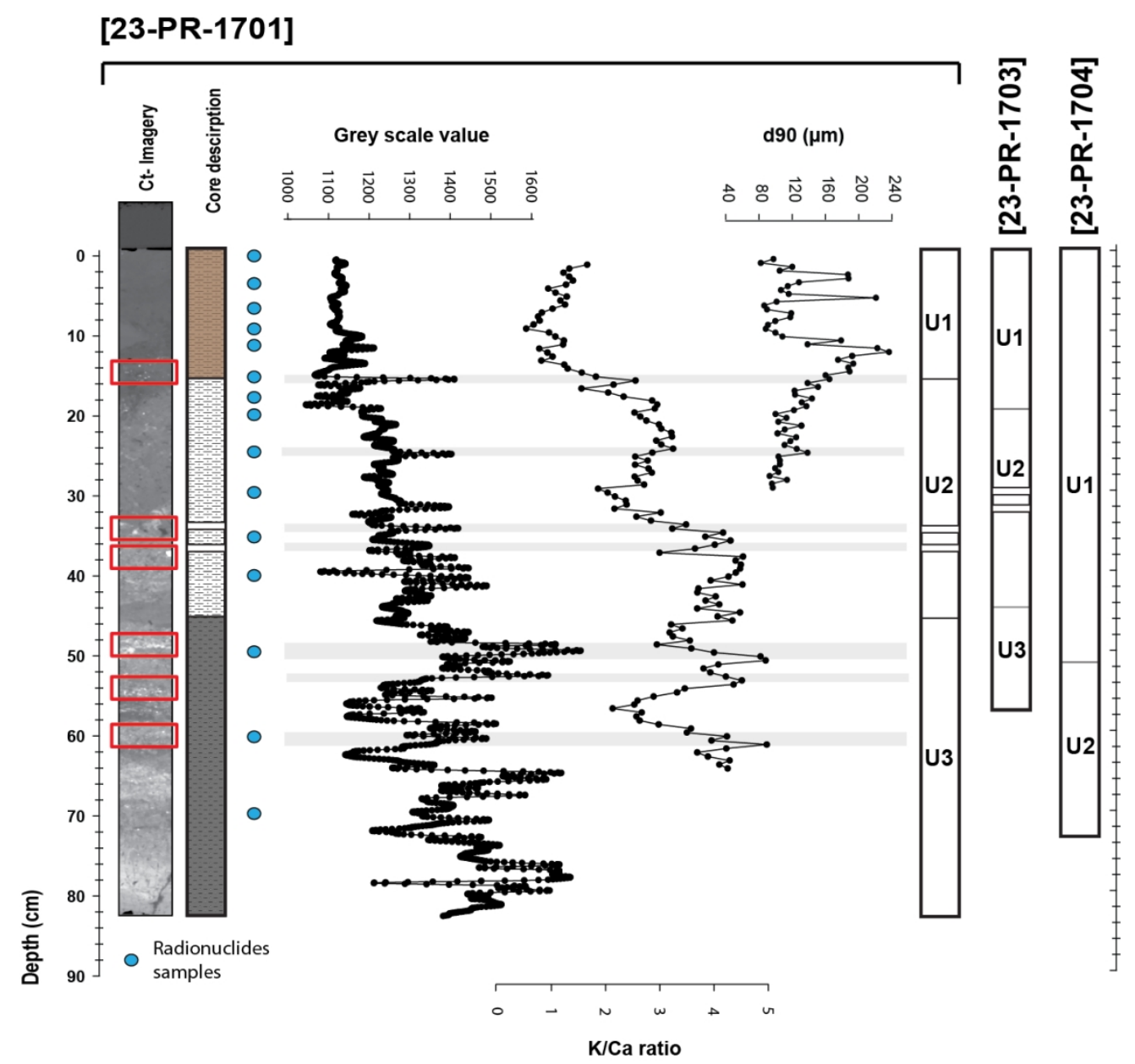

Figure 2: Definition of the sedimentary units along the master core 23-PR-1701 using CT-Scan imagery/grey values, K/Ca ratio and grain size analyses (d90). Correlation with the 23-PR-1702 and 23-PR-1704 cores. 


\section{${ }^{137}$ Cs activity (Bq. $\mathrm{kg}^{-1}$ )}

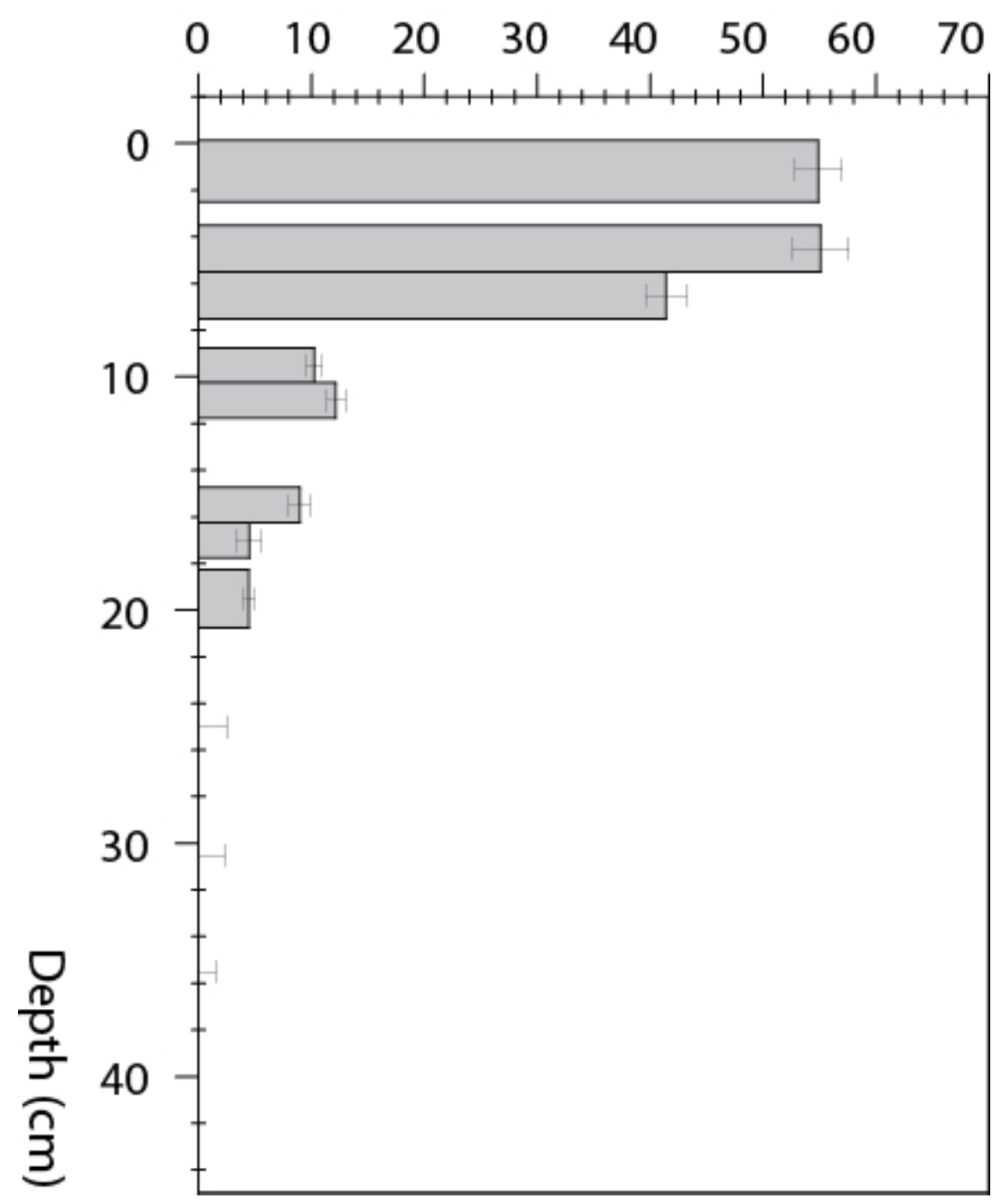

Figure 3: Evolution of $137 \mathrm{Cs}$ activities with depth in core $23-\mathrm{PR}-1701$

$73 \times 99 \mathrm{~mm}(150 \times 150 \mathrm{DPI})$ 


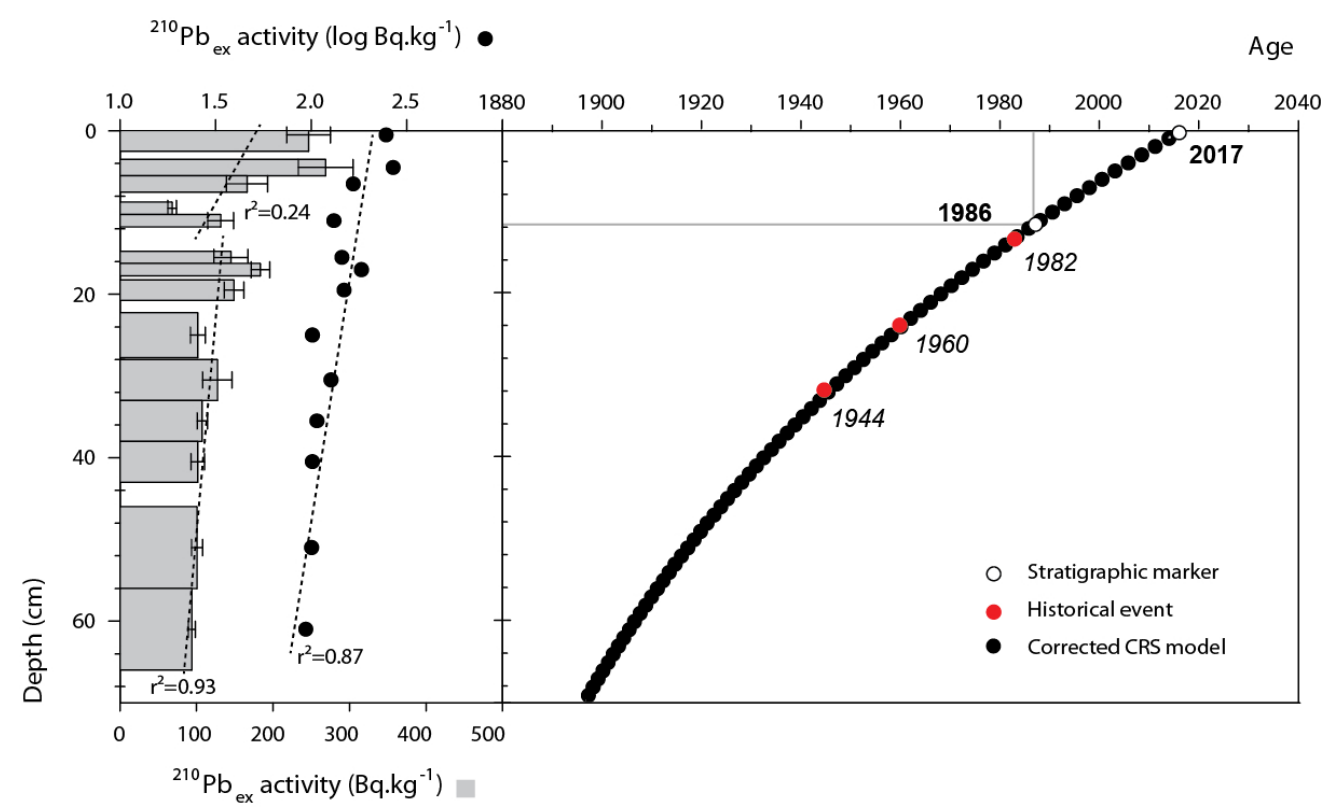

Figure 4: Age depth model of core 23-PR-1701 based on 210Pbex corrected Constant Rate Supply model. Model validation was achieved by the identification of those $137 \mathrm{Cs}$ fallout peaks and the visual identification of sediment layers associated with flood events. 


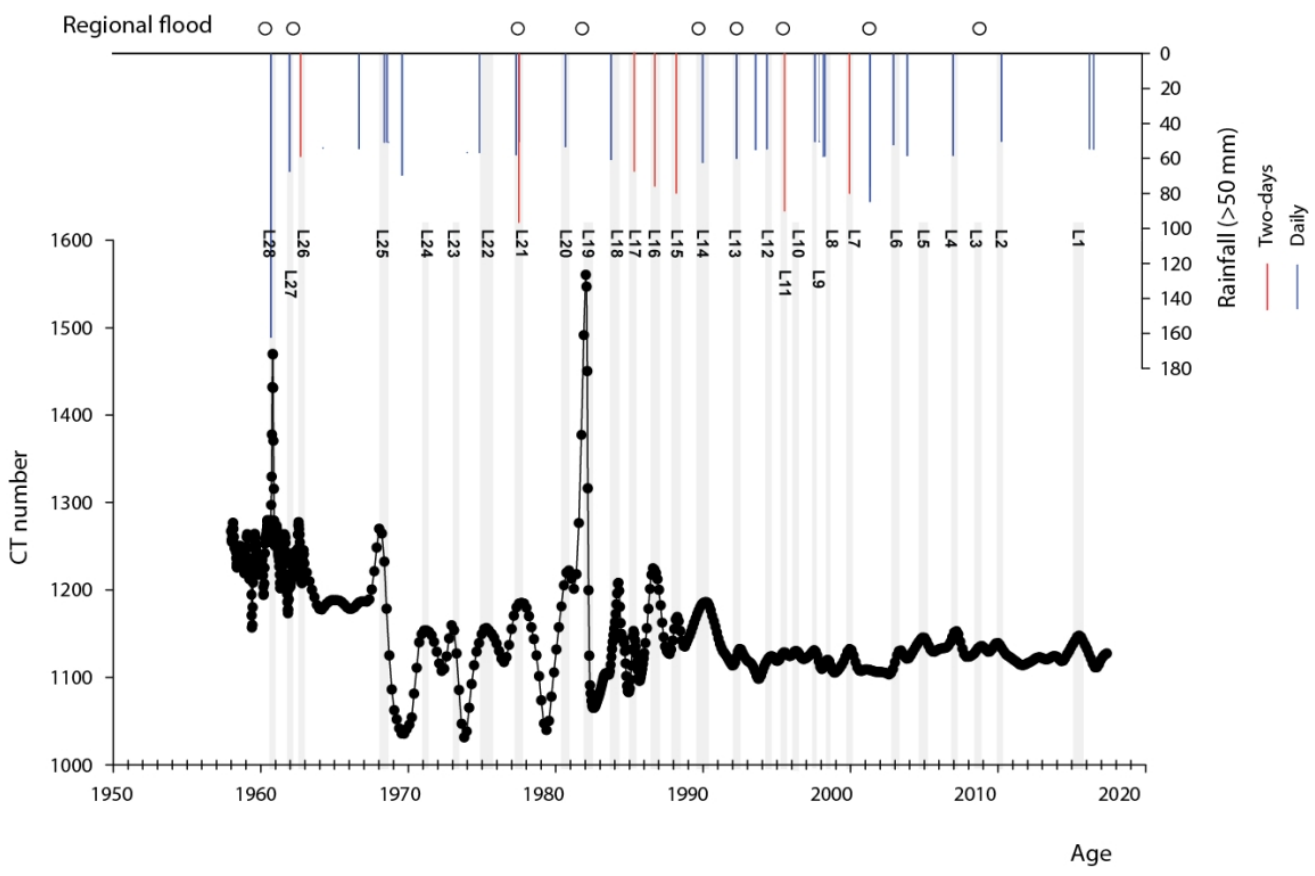

Figure 5: Detection with CT-scan profile of denser layers for the 2017-1960 period. Comparison with daily and two-days extreme rainfall ( $>50 \mathrm{~mm}$ ). 


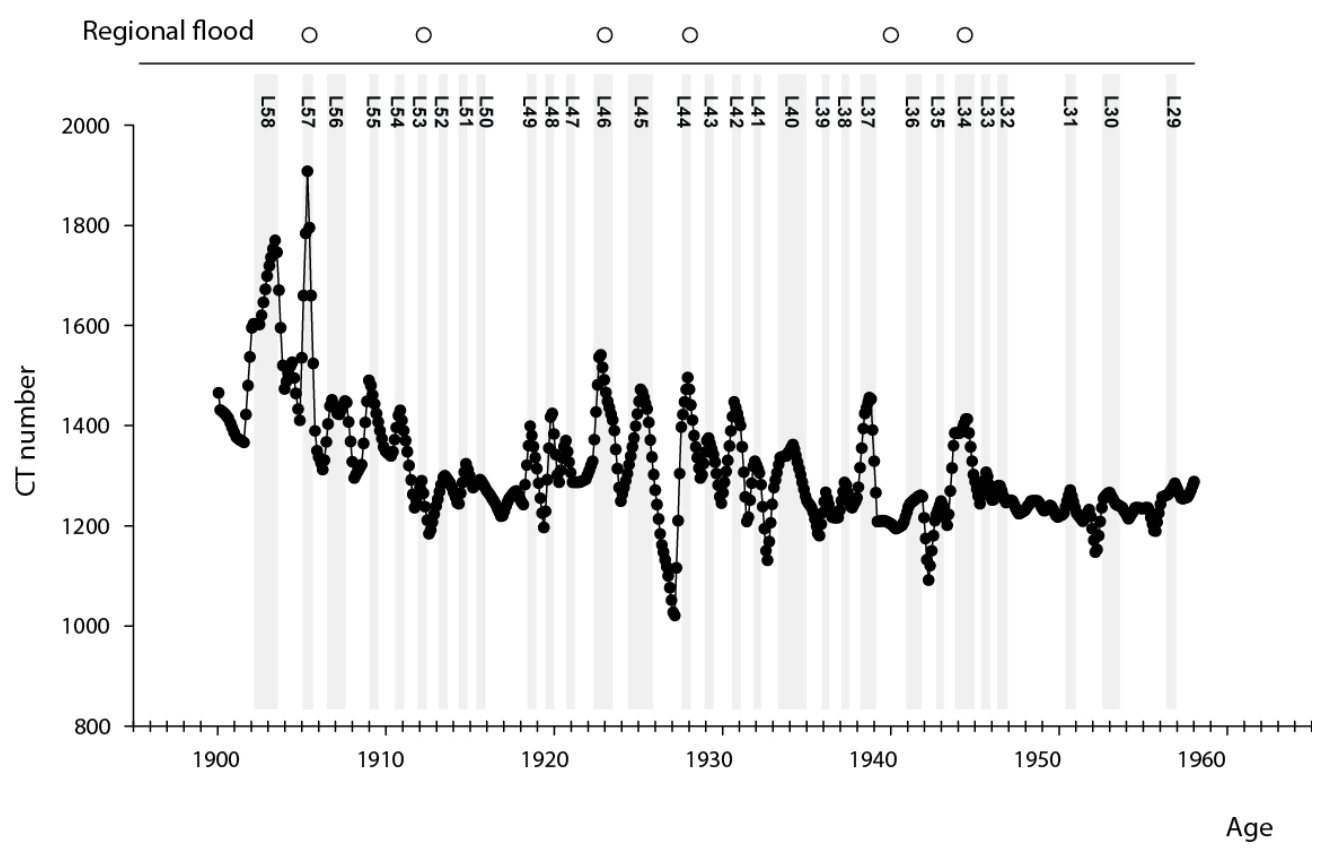

Figure 6: Detection with CT-scan profile of denser layers for the 1960-1900 period.

$195 \times 123 \mathrm{~mm}(150 \times 150 \mathrm{DPI})$ 


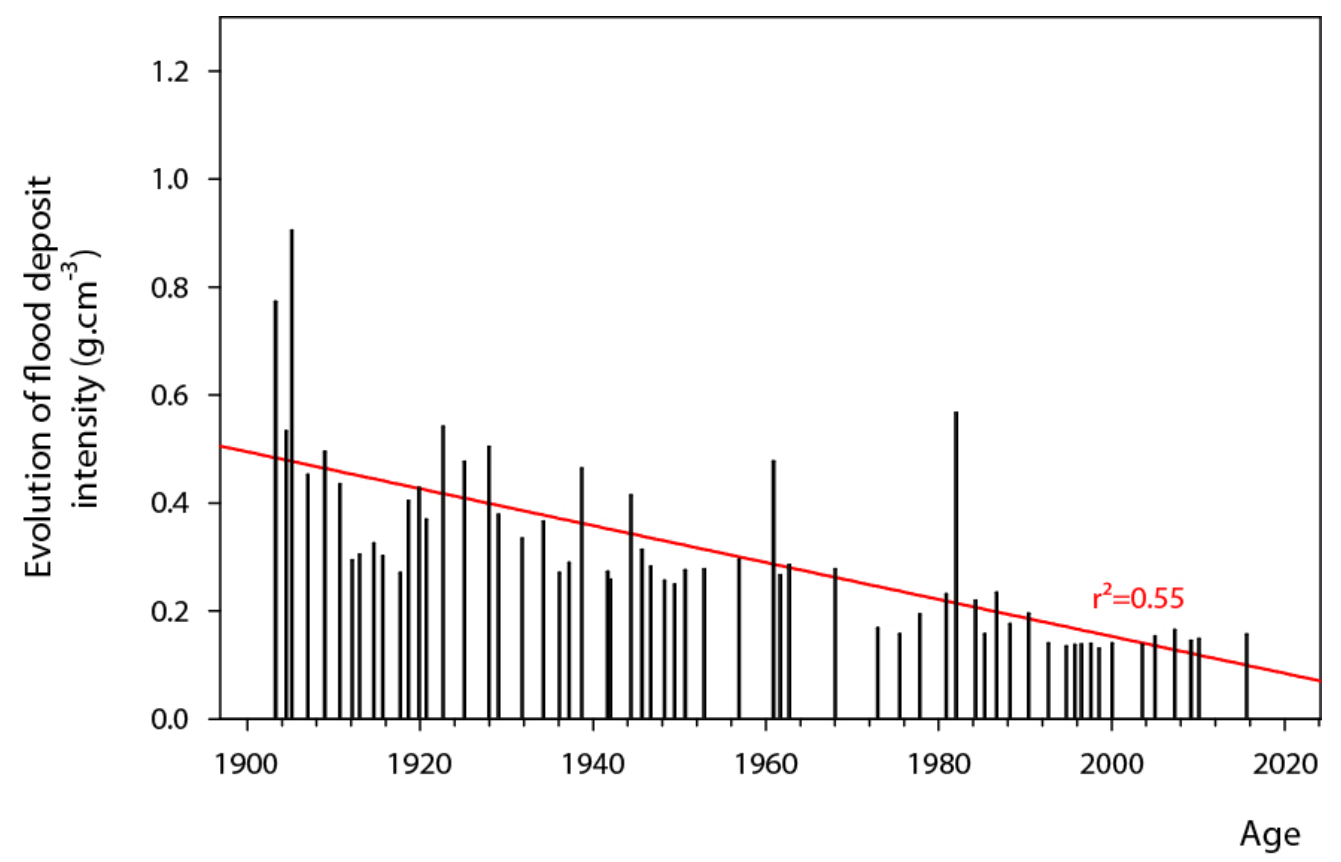

Figure 7: Evolution of flood sediment deposit intensity (g.cm-3) during the last 120 years in the Prugnolas pond using the 23-PR-1701 core

$147 \times 95 \mathrm{~mm}(150 \times 150 \mathrm{DPI})$ 


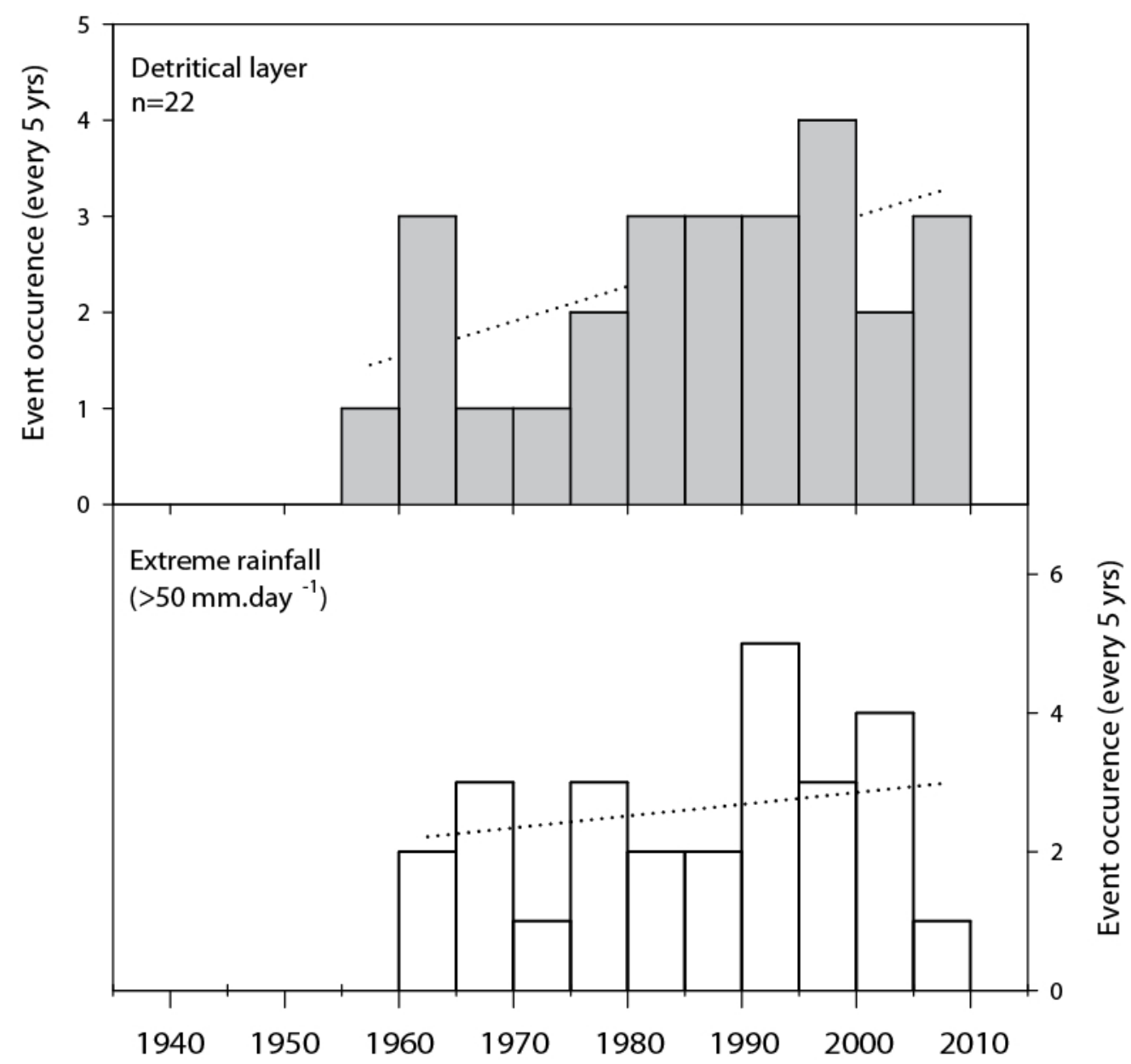

Figure 8: Trend in frequency of heavy rainfall and denser layer records during the monitored period (20171960) years in the Prugnolas pond using the 23-PR-1701 core

$132 \times 124 \mathrm{~mm}(150 \times 150 \mathrm{DPI})$ 


$\begin{array}{llll}\text { Date } & \text { Flood } & \text { Windstorm } & \\ 2009 & + & & \\ 2001 & + & & \\ 1999 & & \text { Major Storm - human and material damage } \\ 1995 & + & & \\ 1993 & + & \text { Major flood } \\ 1990 & + & & \\ 1982 & + & & \text { Extensive flood } \\ 1978 & + & \text { Regional flood - human and material damage } \\ 1962 & + & \\ 1960 & + & \text { Major flood - human and material damage } \\ 1951 & + & \\ 1944 & + & \text { Major flood } \\ 1940 & + & \text { Major flood - large damage } \\ 1927 & + & \text { Major flood } \\ 1923 & + & \text { Major flood } \\ 1912 & + & & \\ 1904 & + & & \end{array}$


Page 31 of 34 


\begin{tabular}{|c|c|c|c|c|c|c|c|c|}
\hline $\begin{array}{l}\text { Layer } \\
\text { label }\end{array}$ & $\begin{array}{c}\text { Depth } \\
(\mathrm{cm})\end{array}$ & Age & $\begin{array}{c}\text { Time } \\
\text { between } \\
\text { two- } \\
\text { events } \\
\text { (yrs) }\end{array}$ & $\begin{array}{c}\text { Layer } \\
\text { density } \\
\text { (g.cm-3) }\end{array}$ & $\begin{array}{c}\text { Layer } \\
\text { Thickness } \\
\text { (cm) }\end{array}$ & $\begin{array}{c}\text { Rainfall } \\
\text { (mm) }\end{array}$ & $\begin{array}{l}\text { Date of } \\
\text { the } \\
\text { rainfall }\end{array}$ & $\begin{array}{c}\text { Age difference } \\
\text { : layer- } \\
\text { meteorological } \\
\text { event }\end{array}$ \\
\hline L1 & 05 & 2016 & & 0.16 & 0.5 & & & \\
\hline L2 & 2.3 & 2010 & 5.5 & 0.15 & 0.3 & 50 & 2010 & -0.4 \\
\hline L3 & 3.3 & 2009 & 0.9 & 0.15 & 0.3 & & & \\
\hline L4 & 3.9 & 2007 & 1.9 & 0.17 & 0.3 & 58 & 2007 & 0.1 \\
\hline L5 & 4.5 & 2005 & 2.3 & 0.15 & 0.2 & & & \\
\hline L6 & 5.6 & 2004 & 1.5 & 0.14 & 0.3 & 52 & 2003 & 0.4 \\
\hline L7 & 6.1 & 2000 & 3.5 & 0.14 & 0.2 & 83 & 2001 & -0.9 \\
\hline L8 & 6.5 & 1999 & 1.5 & 0.13 & 0.3 & 59 & 1998 & 0.2 \\
\hline L9 & 7.0 & 1998 & 0.9 & 0.14 & 0.2 & 50 & 1998 & -0.5 \\
\hline L10 & 7.3 & 1997 & 1.1 & 0.14 & 0.2 & & & \\
\hline L11 & 7.7 & 1996 & 0.7 & 0.14 & 0.2 & 88 & 1995 & 0.6 \\
\hline L12 & 8.6 & 1995 & 1.0 & 0.13 & 0.6 & 54 & 1994 & 0.2 \\
\hline L13 & 9.6 & 1993 & 2.1 & 0.14 & 0.7 & 60 & 1992 & 0.2 \\
\hline L14 & 10.5 & 1990 & 2.3 & 0.20 & 0.2 & 62 & 1990 & 0.2 \\
\hline L15 & 11.1 & 1988 & 2.2 & 0.18 & 0.5 & 84 & 1988 & 0.0 \\
\hline L16 & 12.0 & 1987 & 1.5 & 0.23 & 0.4 & 84 & 1986 & 0.6 \\
\hline L17 & 11.6 & 1985 & 1.4 & 0.16 & 0.2 & 77 & 1985 & -0.1 \\
\hline L18 & 13.1 & 1984 & 1.1 & 0.22 & 0.7 & 61 & 1984 & 0.3 \\
\hline L19 & 15.0 & 1982 & 2.2 & 0.57 & 0.4 & & & \\
\hline L20 & 15.3 & 1981 & 1.1 & 0.23 & 0.2 & 53 & 1981 & 0.1 \\
\hline L21 & 16.1 & 1978 & 3.1 & 0.19 & 0.4 & 97 & 1978 & 0.0 \\
\hline L22 & 16.7 & 1975 & 2.4 & 0.16 & 0.4 & 57 & 1974 & 1.3 \\
\hline L23 & 17.4 & 1973 & 2.5 & 0.17 & 0.2 & & & \\
\hline L24 & 17.8 & 1968 & 4.9 & 0.28 & 0.4 & 51 & 1969 & -0.7 \\
\hline L25 & 18.7 & 1963 & 5.3 & 0.29 & 0.4 & 67 & 1962 & 0.6 \\
\hline L26 & 22.7 & 1962 & 1.0 & 0.27 & 0.6 & 60 & 1962 & -0.2 \\
\hline L27 & 24.4 & 1961 & 0.8 & 0.48 & 0.4 & 162 & 1961 & 0.0 \\
\hline
\end{tabular}




\begin{tabular}{|c|c|c|c|c|c|c|}
\hline Layer label & Depth (cm) & Age & $\begin{array}{c}\text { Interval } \\
\text { between } \\
\text { two-events } \\
\text { (yrs) }\end{array}$ & $\begin{array}{c}\text { Layer } \\
\text { density } \\
(\text { g.cm-3) }\end{array}$ & $\begin{array}{c}\text { Intensity } \\
\text { (\%) }\end{array}$ & $\begin{array}{l}\text { Occurrence } \\
\text { of a } \\
\text { regional } \\
\text { flood }\end{array}$ \\
\hline L29 & 25.2 & 19567 & 3.1 & 0.3 & 39 & \\
\hline L30 & 27.1 & 1953 & 4.0 & 0.3 & 55 & \\
\hline L31 & 28.1 & 1951 & 2.2 & 0.3 & 52 & \\
\hline L32 & 29.9 & 1947 & 4.0 & 0.3 & 39 & \\
\hline L33 & 30.5 & 1946 & 1.0 & 0.3 & 83 & \\
\hline L34 & 31.1 & 1944 & 1.3 & 0.4 & 286 & + \\
\hline L35 & 32.2 & 1942 & 2.4 & 0.3 & 69 & \\
\hline L36 & 33.3 & 1942 & 0.3 & 0.3 & 89 & \\
\hline L37 & 33.7 & 1939 & 3.0 & 0.5 & 365 & \\
\hline L38 & 34.4 & 1937 & 1.5 & 0.3 & 114 & \\
\hline L39 & 35.5 & 1936 & 1.2 & 0.3 & 86 & \\
\hline L40 & 35.8 & 1934 & 1.8 & 0.4 & 255 & \\
\hline L41 & 36.9 & 1932 & 2.5 & 0.3 & 160 & \\
\hline L42 & 37.3 & 1931 & 0.8 & 0.4 & 185 & \\
\hline L43 & 38.2 & 1929 & 1.9 & 0.4 & 101 & \\
\hline L44 & 38.7 & 1928 & 1.1 & 0.5 & 282 & + \\
\hline L45 & 40.0 & 1925 & 2.9 & 0.5 & 292 & \\
\hline L46 & 41.1 & 1923 & 2.4 & 0.5 & 345 & + \\
\hline L47 & 41.9 & 1921 & 2.0 & 0.4 & 105 & \\
\hline L48 & 42.7 & 1920 & 0.8 & 0.4 & 190 & \\
\hline L49 & 42.8 & 1919 & 1.2 & 0.4 & 207 & \\
\hline L50 & 44.1 & 1916 & 3.0 & 0.3 & 24 & \\
\hline L51 & 44.5 & 1915 & 1.0 & 0.3 & 109 & \\
\hline L52 & 45.2 & 1913 & 1.6 & 0.3 & 79 & \\
\hline L53 & 45.6 & 1912 & 0.9 & 0.3 & 65 & + \\
\hline L54 & 46.1 & 1911 & 1.4 & 0.4 & 127 & \\
\hline L55 & 46.8 & 1909 & 1.8 & 0.5 & 247 & \\
\hline L56 & 47.6 & 1907 & 2.0 & 0.5 & 178 & \\
\hline L57 & 48.4 & 1905 & 1.8 & 0.9 & 692 & \\
\hline
\end{tabular}




$\begin{array}{lllllll}\text { L58 } & 48.6 & 1904 & 0.7 & 0.5 & 72 & + \\ \text { L59 } & 49.1 & 1903 & 1.2 & 0.8 & 563\end{array}$

